\title{
UDC 636.5.084.5.639.09:614.95
}

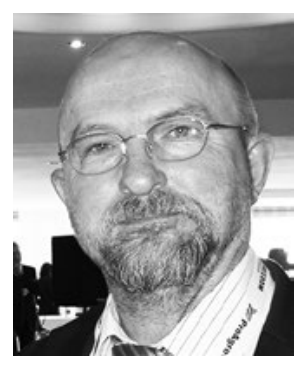

PETER F. SURAI, PhD, DSC, Professor

Trakia University, Stara Zagora 6000, Bulgaria,

Moscow State Academy of Veterinary Medicine and Biotechnology named after K.I. Skryabin, Moscow, 109472, Russia,

Szent Istvan University, Gödöllo H-2103, Hungary,

Saint-Petersburg State Academy of Veterinary Medicine, St. Petersburg, Russia,

Sumy National agrarian University, Sumy, Ukraine,

Odessa National Academy of Food Technologies, Odessa, Ukraine,

Russian Academy of Sciences, Moscow, Russia

E-mail:psurai@feedfood.co.uk

\section{Vitagenes in poultry production: stresses and antioxidants}

\begin{abstract}
Commercial poultry production is related to a range of various stresses. A growing body of evidence indicates that excess ROS/RNS production, disturbance of redox balance and oxidative stress are major molecular mechanisms of the most common commercial stresses in poultry production. During evolution, antioxidant defence systems were developed in birds to survive in an oxygenated atmosphere. It seems likely that all antioxidants in the body work cooperatively together as a team to maintain optimal redox balance in the cell/body. Nutritional modulation of vitagenes is considered as a new direction in nutritional research. Therefore, there is an opportunity to activate a range of vitagenes to maximise internal $A O$ protection and maintain redox balance and improve stress resistance. Since ROS/RNS are considered to be important signalling molecules, their concentration is strictly regulated by the antioxidant defence network associated with various transcription factors and vitagenes.
\end{abstract}

Key words: poultry, stress, antioxidants, molecular mechanism, vitagenes

\section{Introduction}

It is well appreciated that commercial poultry production is associated with a range of environmental, technological, nutritional and internal/biological stresses, responsible for decreased productive and reproductive performance and compromised health (Surai and Fisinin, 2016a; 2016b). Generally speaking, many stress conditions could be avoided by technological improvements, but the main restriction is the cost of such improvements. Accumulating evidence indicates that at the molecular/cellular level most commerciallyrelevant stresses in poultry production are associated with overproduction of free radicals, compromised antioxidant defences network and oxidative stress (Surai, 2018; Surai et al., 2018; 2019). It has been clearly shown that free radicals in the form of reactive oxygen species (ROS) and reactive nitrogen species (RNS) are damaging to all types of biological molecules including polyunsaturated fatty acids (PUFAs), proteins and DNA. Furthermore, signaling roles of ROS have recently received tremendous attention. Indeed, adaptation to various stresses relies on various signaling pathways and vitagenes were shown to play crucial roles in such an adaptation (Surai and Fisinin, 2016c; 2016d; Surai et al., 2019). Therefore, the main task of this review is to present an updated view on the commercially relevant stresses in relation to the antioxidant defence network in poultry.

\section{Main stresses in Poultry Production}

As mentioned above, commercial poultry production is associated with a range of various stresses (Table 1). Therefore, an important task for poultry nutritionist is to develop a nutritional program meeting poultry requirement in major nutrients.

However, it is very difficult to predict stresses in commercial poultry production and to develop an optimal program to deal with them. On one hand, in stress conditions requirement in various nutrients increase. On the other hand, feed consumption in stress conditions usually decreased. Therefore, at times when birds need more nutrients they actually 


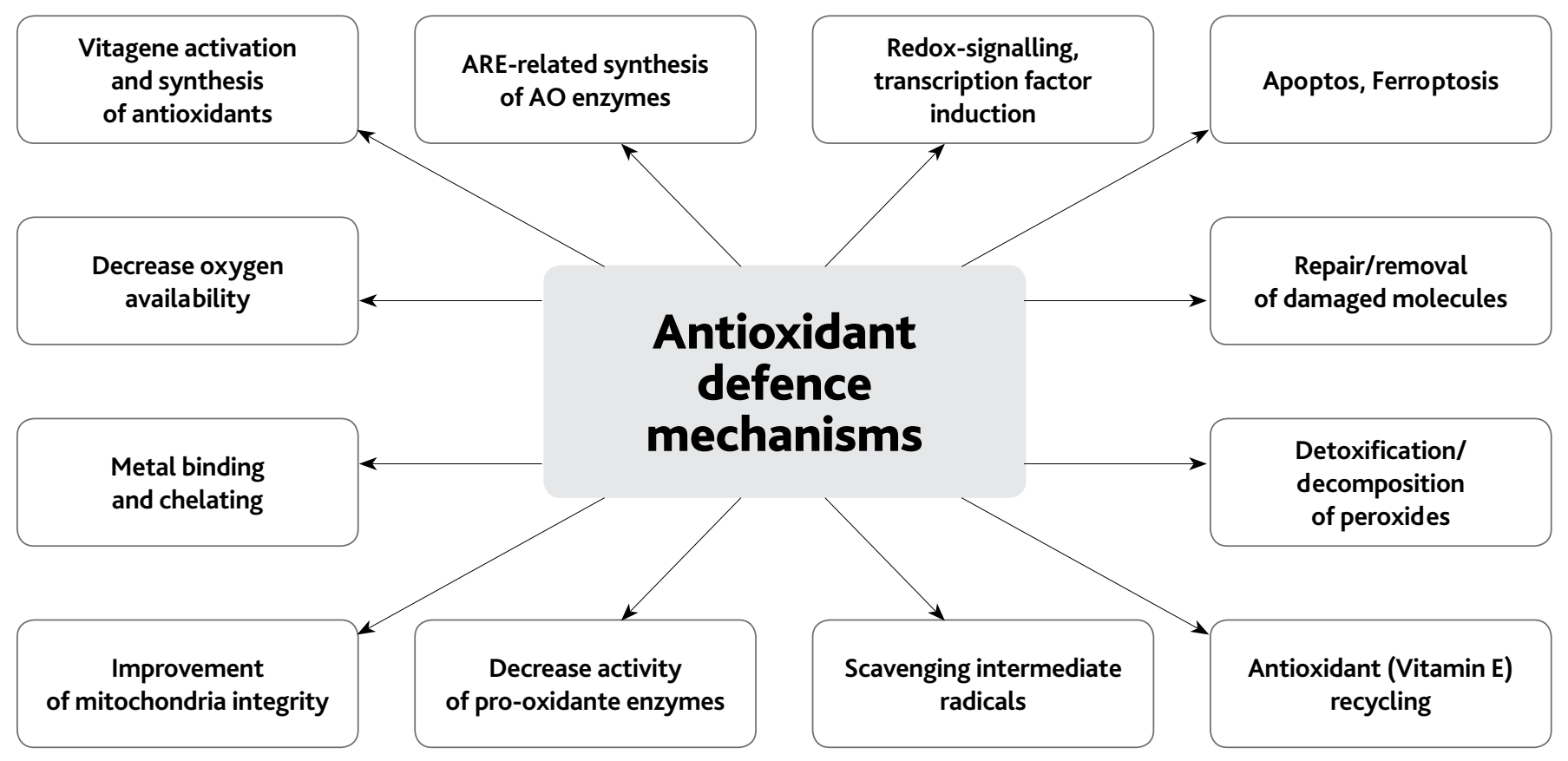

Figure 1. Antioxidant defence mechanisms (adapted from Surai et al., 2019).

have less. Therefore, various antistress premixes and additives added with feed showed a variable efficacy.

\section{Table 1. Main stressors in poultry production} (adapted from Surai et al., 2019)

\begin{tabular}{|l|}
\multicolumn{1}{|c|}{ Technological stressors } \\
\hline Chick placement \\
\hline Increased stocking density \\
\hline $\begin{array}{l}\text { Weighing, grading, group formation, catching, transferring } \\
\text { to breeder houses }\end{array}$ \\
\hline $\begin{array}{l}\text { Prolonged egg storage, egg transportation, inadequate egg } \\
\text { storage conditions, incorrect incubation regimes }\end{array}$ \\
\hline Inadequate temperature \\
\hline Inadequate ventilation and increased dust \\
\hline Inadequate lightning \\
\hline \multicolumn{1}{|c|}{ Nutritional stressors } \\
\hline Mycotoxins \\
\hline Oxidised fat \\
\hline Toxic metals (lead, cadmium, mercury, etc.) \\
\hline $\begin{array}{l}\text { Imbalance of minerals (Se, Zn, Mn, Cu, etc.) and other } \\
\text { nutrients }\end{array}$ \\
\hline Low water quality \\
\hline Usage of coccidiostats and other drugs via feed or water \\
\hline \multicolumn{1}{|c|}{ Internal stressors } \\
\hline Vaccinations \\
\hline Microbial or virus challenges \\
\hline Gut dis-bacteriosis \\
\hline Pipping and hatching \\
\hline
\end{tabular}

\section{Antioxidant defence network}

To address the aforementioned question, molecular mechanisms of stress development have been studies in details. The updated view on the antioxidant defence network is shown in Figure 1.

As can be seen from the Figure 1, there is a range of important options to maintain antioxidant defences in the cell/body. First of all, oxygen availability is a key regulator of free radical formation and a decreased oxygen availability could decrease ROS formation and less antioxidants would be needed to deal with a situation. Since, free iron and copper are major catalysers of ROS formation, their binding to proteins or chelating are important steps in AO defences. It is well known that mitochondria are major source of ROS in the living cells and supporting mitochondria integrity by such nutrients as carnitine, taurine or silymarin are of major importance for the antioxidant defence network. There is also an important option to decrease ROS-producing enzyme activities to control antioxidant defences. Scavenging intermediate free radicals, for example, superoxide radical by SOD in mitochondria, is considered as the first level of the antioxidant defence network. Further detoxification of the such toxic products as $\mathrm{H} 2 \mathrm{O} 2$ or lipid hydroperoxides by such enzymes as GPx and non-enzymatic antioxidants (vitamin E, GSH, coenzyme $Q$, etc.), plays a vital role in antioxidant defences. In particular, it is well accepted that vitamin $\mathrm{E}$ is the main chain-breaking antioxidant in biological membranes, but after catching a free radical alpha-tocopherol is oxidised and if not reduced back it is lost. Therefore, biological vitamin E recycling by ascorbic acid and further recycling with involvement of Se-dependent enzyme thioredoxin reductase, riboflavin-dependent glutathione reductase and other elements connecting to pentose phosphate cycle as a source of HADPH is a most important part of the antioxi- 


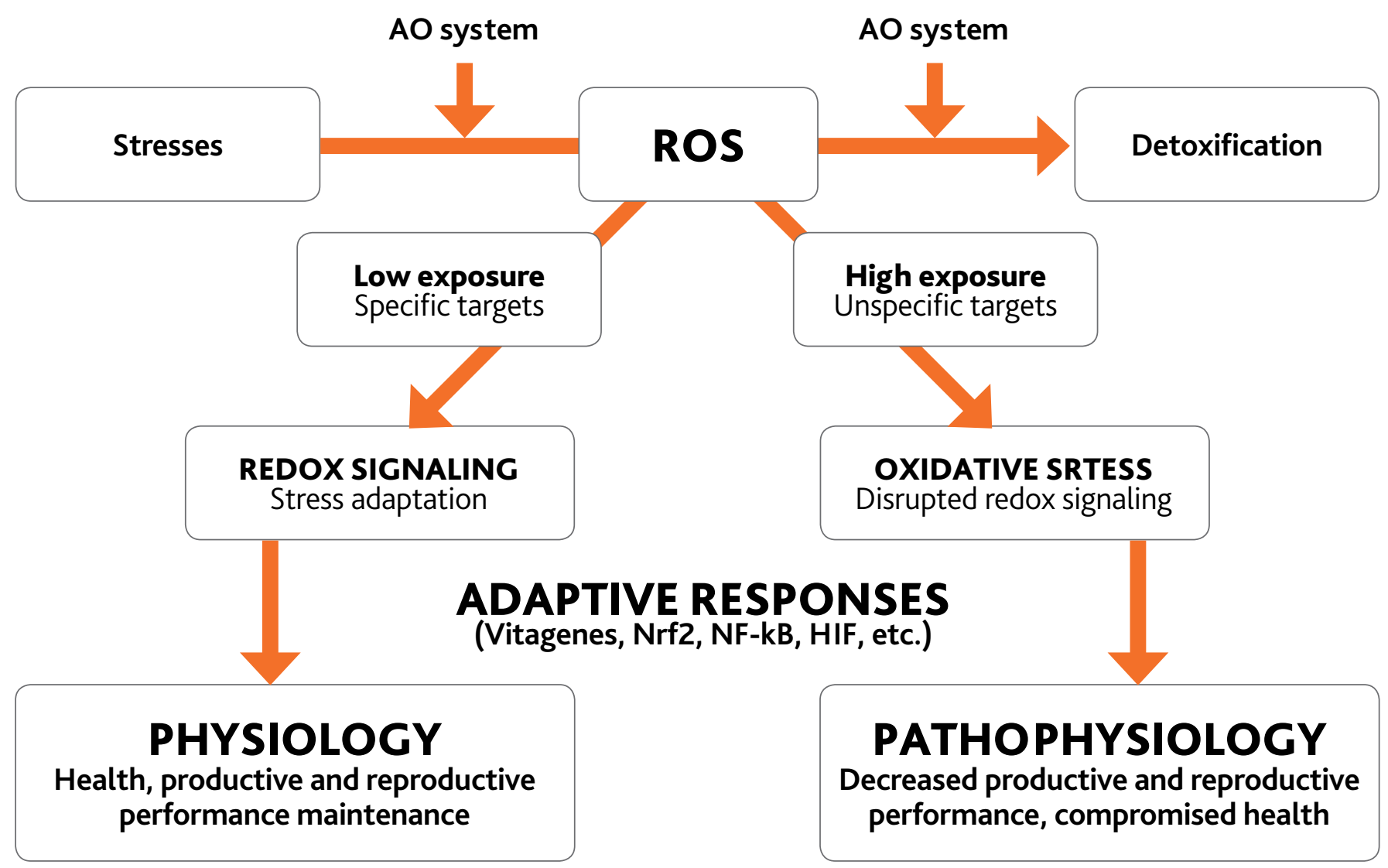

Figure 2. Oxidative stress and adaptive responses (adapted from Surai et al., 2019).

dant defence strategy. Indeed, in the case of effective vitamin $\mathrm{E}$ recycling even low dietary vitamin $\mathrm{E}$ doses can deal with overproduction of ROS, while in the case of non-effective vitamin $\mathrm{E}$ recycling even high vitamin E dietary supplementation would not have adequate protective effect. All the aforementioned mechanisms of the antioxidant defence are still not able to prevent damages to biological molecules and therefore repair of the damaged molecules (e.g. HSP, methionine sulphoxide reductase, DNA-repair enzymes, etc.) or their removal (phospholipases, etc.) are deeply involved in the antioxidant defences. Interestingly, if the stress is too high and the antioxidant defences are not able to deal with it and there is an accumulation of damaged molecules such processes as apoptosis and ferroptosis would kill the damaged cell to prevent transferring damages to other cells. Furthermore, redox signaling and activation of various transcription factors (HSF, Nrf2, $\mathrm{NF}-\mathrm{kB}$, etc.) are key players in adaptation to stress and decreasing detrimental consequences of the oxidative stress. In particular, antioxidant response element (ARE)-related synthesis of antioxidant enzymes is considered to be the main adaptive response mediated by transcription factor Nrf2. Finally, activation of vitagenes via Nrf2, HSF and other transcription factors is a recent entrant into the antioxidant defence family.

\section{Stress and adaptation}

A modern view on stress adaptation is shown in Figure 2.

As mentioned above, overproduction of ROS and oxidative stress are major molecular mechanisms of various stresses. Indeed, independently of the source of stress (e.g. increased temperature, high amount of dust in air, mycotoxins in the feed or vaccination stress, etc.) at the molecular level ROS overproduction and damages to biological molecules are driving forces of the detrimental consequences in terms of chicken health. Their productive and reproductive performance. Therefore, when antioxidant defence system can deal with those free radicals, the small amount of ROS participates in cell signaling providing an important mechanism of stress adaptation. In particular, they activate such transcription factors as Nrf2 or HSFs, with following vitagene activation and additional synthesis of protective molecules (antioxidants) to maintain adaptive homeostasis. However, when stress is too high and antioxidant defence system cannot prevent damages to PUFAs, proteins and DNA oxidative stress is responsible for activation of other transcription factors, including NF-kB leading to synthesis of pro-inflammatory cytokines and inflammation, compromised immunity and general health. This is associated with decreased productive and reproductive performance of growing chickens, rearing birds, layers and breeders. 
П.Ф. СУРАЙ, gоктор філософії, gоктор

біологічних наук

Тракійскій університет, Стара Загора, Болгарія,

Московська gержавна акаgемія ветеринарноі

меgицини та біотехнології імені Скрябіна,

Москва, Росія

Університет Святого Іштвана, Гоgоло, Угорщина,

Санкт-Петербурзька акаgемія ветеринарної меgицини, Санкт-Петербург, Росія,

Сумський національний аграрний університет,

Суми, Україна,

Оgеська національна акаgемія харчових технологій, Ogеса, Украӥна,

Російська акаgемія наук, Москва, Росія

E-mail:psurai@feedfood.co.uk

\section{Вітагени у птахівництві: стреси та антиоксиданти}

Анотація. Промислове птахівництво пов'язане з низкою стресів. Дані останніх років переконливо свідчать про те, що надмірне утворення вільних радикалів, порушення редокс-балансу і окислювальний стрес $\epsilon$ головними молекулярними механізмами більшості стресів у птахівництві. В процесі еволюції у птахів були вироблені спеціальні антиоксидантні механізми, що дозволяють ім вижити в атмосфері з високим вмістом кисню. Вважається, що всі антиоксиданти в організмі працюють спільно як одна команда, яка підтримує оптимальний редокс-баланс в клітинах/організмі. Активація вітагенів різними нутрієнтами вважається новим напрямом у дослідженнях щодо живлення. При цьому активація вітагенів у стресумовах дозволяє підсилити антиоксидантний захист, підтримати окислювально-відновний баланс в організмі і підвищити стійкість до стресів. Таким чином, існує можливість активувати ряд вітагенів для максимального антиоксидантного внутрішнього захисту і підвищення стресостійкості. Оскільки вільні радикали розглядаються в якості найважливіших сигнальних молекул, їх концентрація в клітині регулюється антиоксидантною системою, пов'язаної $з$ різними факторами транскрипції і вітагенами.

\section{П.Ф. Сурай}

\section{Витагены в птицеводстве: стрессы и антиоксиданты}

Аннотация. Промышленное птицеводство сопряжено с рядом стрессов. Данные последних лет убедительно свидетельствуют о том, что избыточное образование свободных радикалов, нарушение редокс-баланса и окислительный стресс являются главными молекулярными механизмами большинства стрессов в птицеводстве. В процессе эволюции у птиц были выработаны специальные антиоксидантные механизмы, позволяющие им выжить в атмосфере с высоким содержанием кислорода. Считается, что все антиоксиданты в организме работают сообща как одна команда, поддерживающая оптимальный редокс-баланс в клетках/организме. Пищевая активация витагенов считается новым направлением в исследованиях в области питания. При этом активация витагенов в стресс-условиях позволяет усилить антиоксидантную защиту, поддержать окислительно-восстановительный баланс в организме и повысить устойчивость к стрессам. Таким образом, существует возможность активировать ряд витагенов для максимальной внутренней антиоксидантной защиты, поддержания окислительно-восстановительного баланса и повышения стрессоустойчивости. Поскольку свободные радикалы рассматриваются в качестве важнейших сигнальных молекул, их концентрация в клетке регулируется антиоксидантной системой, связанной с различными факторами транскрипции и витагенами.

Ключевые слова: птицеводство, стресс, антиоксиданты, молекулярный механизм, витагень

Ключові слова: птахівництво, стрес,

антиоксиданти, молекулярний механізм, вітагени

\section{References}

Surai, P.F. (2018). Selenium in Poultry Nutrition and Health; Wageningen Academic Publishers: Wageningen, The Netherlands. 430. https://doi. org/10.3920/978-90-8686-865-0

Surai, P.F. Fisinin, V.I. (2016a). Vitagenes in poultry production. Part 1. Technological and environmental stresses. Worlds Poult. Sci. J. 72. 721-733.

Surai, P.F., Fisinin, V.I. (2016b). Vitagenes in poultry production. Part 2. Nutritional and internal stresses. Worlds Poult. Sci. J. 72. 761-772.

Surai, P.F., Fisinin, V.I. (2016c). Vitagenes in poultry production. Part 3. Vitagene concept development. Worlds Poult. Sci. J. 72. 793-804.

Surai, P.F., Fisinin, V.I. (2016d). Antioxidant system regulation: From vitamins to vitagenes. In Handbook of Cholesterol; Watson, R.R.; de Meester, F., Eds.;

Wageningen Academic Publishers: Wageningen, The Netherlands. 451-481.

Surai, P.F., Kochish, I.I., Fisinin, V.I., Kidd, M.K. (2019). Antioxidant Defence Systems and Oxidative Stress in Poultry Biology: An Update. Antioxidants (Basel). 8. 7. pii: E235. doi: $10.3390 / a n t i o x 8070235$. 